\title{
Philosophy, Well Being and the Identity of Catholic Universities
}

Jovito V. Cariño

\begin{abstract}
In his book, God, Philosophy, Universities, Alasdair MacIntyre traces the history of Catholic philosophical thinking and shows the mutual influence between philosophy and the university. In the same work, Macintyre also highlights the single question which he says should be preeminent in the mind of Catholic thinkers today: the question of what it means to be a human being. Reflection on this matter acquires urgency in the face of dramatic political, cultural and economic changes taking place worldwide. The university, herself an agent of change, is not immune to these transformations. That it must evolve as it adapts to them is an imperative which the university cannot afford to ignore but as argued by this paper, such adaptation must begin from a sincere critique and reaffirmation of the university's identity as cultivator of humanity. This paper maintains that Catholic universities like UST cannot turn their back on their humanistic commitments. The humanities, of which philosophy is a primary discipline, is what defines the identity of a university as an alma mater. It is what enables the university to cultivate the individual towards its flourishing both as a citizen of the local society and as a citizen of the world.
\end{abstract}

Keywords: MacIntyre, Catholic university, University of Santo Tomas, humanities

\section{Introduction}

7 he school year 2011-2012 marks the fourth centenary of the University of Santo Tomas. This is a singular feat and one that warrants a grand celebration; but beside the festivities which trumpet the university's storied past, the occasion is also an invitation for the university to re-affirm its fundamental identity in the face of rising global changes. As it celebrates the past and gears up for the future, members of the UST academic community, individually and collectively, may wish to ask themselves: What does it mean to be a university in the global age? The assertion of one's identity, I think, is the current 


\section{IDENTITY OF CATHOLIC UNIVERSITIES}

pressing challenge for any university hence, the title of this paper. It takes the cue from Alasdair MacIntyre's God, Philosophy, Universities: A Selective History of the Catholic Philosophical Tradition ${ }^{1}$ where he highlights the crucial role of philosophy in the formation of Catholic universities' identity. I begin this paper by saying that the identity of the university today is seriously undermined by the proliferation of what MacIntyre called "managerial culture" and that as a result, it faces the challenge to re-found itself not simply by riding in the wind of the changing times but moreso, by rediscovering its true nature or "what it takes for it to be", according to Aristotle and Aquinas. Following MacIntyre's insights, I shall proceed by providing a description of the so-called global age and its impact on education. This is followed by an account of the nature of university and the kind of education that is shaping up as a result of globalization. From there, I shall discuss the importance of philosophy in asserting the identity of university amidst the tide of global changes. The concluding part will underscore Thomistic philosophy and how it can help a university like the University of Santo Tomas remains faithful to its mission and identity against the tectonic shifts brought about by globalization.

\section{The Global Age}

The term "global" or "globalization" is commonly perceived as a positive expression. For most people, it connotes upgrade or a higher level of acceptability and recognition. Products known to have met global standards easily inspire confidence and draw public attention. Schools themselves are aware of this. Their efforts to identify themselves as "global" or "globalized" are given evidence by the constant use of the word in their mission-vision statements, websites, billboards, posters, brochures and other promotional materials. It has become a marketing mantra. By owning the term "global", schools wish to suggest that the education they offer is well within par.

Although originally a term descriptive of world economy, globalization overtime became closely associated with mass media and information technology as we saw in the high speed decade of the 90's. This convergence of free trade and the information freeway led to the further shrinking, or to use Tom Friedman's expression, flattening of the world. ${ }^{2}$ Science and technology are the new language of progress. They dictate the new world standard for governments, business organizations as well as educational institutions. Thanks to technology, teachers

${ }^{1}$ Alasdair MacIntyre, God, Philosophy, Universities: A Selective History of the Catholic Philosophical Tradition (Plymouth, UK: Rowman \& Little Publishers, Inc., 2009).

${ }^{2}$ For a very readable description of what goes on in globalization, see Tom Friedman, The Lexus and The Olive Tree (New York: Anchor Books, 2000) and The World Is Flat (New York: Picador, 2007).

(C) 2012 Jovito V. Cariño http://www.kritike.org/journal/issue 11/carino june2012.pdf ISSN 1908-7330 
can now lecture in online classrooms and use laptops, instead of blackboards, for presentation. Cellphones and tablets have become handy tools for research and note taking of students. Through Wi-Fi connection, the campus is able to extend itself beyond its local environment. Science and information technology make things easy, quick and systematic via the parallel universe called the world wide web.

The real impact of globalization to education, however, goes beyond the introduction of hi-tech teaching and learning tools. Its net effect, according to Jean Francois Lyotard, comes in the form of "exteriorization of knowledge." In his work entitled, The Postmodern Condition: A Report on Knowledge, Lyotard rightly observes how in the post-war, post-industrial societies such as ours, knowledge is becoming more and more exteriorized. Exteriorization of knowledge refers to the generation of knowledge apart from the development of the individual or Bildung, the traditional German word for culture or the paideia of the Greeks. Once extracted from its natural cultural milieu, knowledge becomes commodified, something that is produced or manufactured for the benefit of commercial exchange or to put it bluntly, for the sake of its market value. Knowledge becomes the new "force of production", giving rise to what is now known as knowledgedriven economy. This is the new economic order whose main concentration is knowledge generation. According to Lyotard, knowledge will be the new battleground among competing states. Whoever controls and enjoys greater access to knowledge production ultimately controls power. It is for this reason that Lyotard sees the preeminence of science in the current and coming centuries. Lyotard writes:

It is widely accepted that knowledge has become the principle force of production over the last few decades. This has already had a noticeable effect on the composition of the work force of the most highly developed countries and constitutes the major bottleneck for the developing countries. In the postindustrial and postmodern age, science will maintain and no doubt strengthen its preeminence in the arsenal of productive capacities of the nation-states. Indeed, this situation is one of the reasons leading to the conclusion that the gap between developed and developing countries will grow ever wider in the future. ${ }^{3}$

${ }^{3}$ Jean-Francois Lyotard, The Postmodern Condition: A Report On Knowledge (Minneapolis: University of Minnesota Press, 1999), 5.

(C) 2012 Jovito V. Cariño http://www.kritike.org/journal/issue 11/carino june2012.pdf ISSN 1908-7330 


\section{IDENTITY OF CATHOLIC UNIVERSITIES}

Countries who have shifted gears towards knowledge economy are now the ones reaping bountiful economic gains. As they engage in producing new knowledge, they become more and more dependent on workers from developing countries like the Philippines to fill in the less knowledge-intensive job requirements for them. This is where our domestic helps, masons, welders, caregivers and call center agents come in. They are prized because they are skilled, meaning, they are adept in consuming knowledge but ill-equipped to produce it. An education that provides students with a high-level of competitive skills in whatever field is undeniably a must. What causes alarm is when education is done solely for knowledge consumption, that is, when students and schools alike become mere functionaries of the economic goals of corporate giants. In a knowledge-consuming and skill-based economy, universities become mere diploma mills or should I say, satellite "human resource departments" or "training facilities" of business institutions who think that the universities' ultimate goal is the optimum compliance with the demands of the job market. Edberto M. Villegas of the University of the Philippines says:

Within this knowledge milieu, universities have shirked from the inculcation of social responsibility among its students, consequently breeding mostly go-getters and socially-indifferent humans. The situation has been aggravated by the phasing-out of social science and art subjects in favor of technical and business courses favorable to the interests of private corporations, in the era of globalization of monopoly capitalism. Education to form the well-rounded person, the generalist-oriented individual, has been considered less important compared to the molding of technical and scientific specializations. The techno-freak has been a product of this emphasis on specialization in contrast with education in the past ages of humanity when the development of the socially aware and compassionate person was highly valued, the Renaissance man in European classical education and the great man in Confucian education. ${ }^{4}$

The situation of the universities in the Philippines provides an image to the very palpable decline of the state of academic enquiry decried by MacIntyre in Three Rival Versions of Moral Enquiry. As he explained, universities regressed

${ }^{4}$ Edberto M. Villegas, "Liberalism, Neoliberalism and the Rise of Consumerist Education," in Bienvenido Lumbera et. al eds., Mula Tore Patungong Palengke: Neoliberal Education In The Philippines (Quezon City, Philippines: IBON Foundation, 2007), 27.

(C) 2012 Jovito V. Cariño

http://www.kritike.org/journal/issue 11/carino june2012.pdf

ISSN 1908-7330 
when "academic enquiry increasingly became professionalized and specialized and that formal education correspondingly became a preparation for and initiation into professionalization and specialization but that, for the most part and increasingly, moral and theological truth ceased to be recognized as objects of substantive enquiry and instead were relegated to the realm of privatized beliefs." ${ }^{\text {s }}$

Because knowledge is commodified, the educative experience is deemed merely as a sprint to the finish line, i.e., employment. The notion of education as an end in itself has become too outdated. More and more, students look at university education as a bridge to someplace else but not as a destination. School has ceased to be an exciting, engaging frontier and has become a glorified waiting lounge for that first job interview. A freshman comes to school and the first thing he dreams of is the day when he leaves it. This itch for an easy school ride is matched by various schools with their offer of smorgasbord of crash courses and short-term programs with some even providing a guarantee of employment offshore. The "labor market" has taken over the classic humanistic goals of learning. John Stuart Mill's famous injunction that he would rather be a hungry Socrates than a well satisfied pig no longer finds a hearing these days and anyone who still subscribes to it is dismissed either as a dimwit or a misfit.

This is not to say that the identity problem of university vis-a-vis the commodification of education exists only in slow developing economies like the Philippines. Apparently, the same crisis plagues universities even in more progressive countries. These universities have transformed themselves into successful business ventures thanks to their rich endowments and bountiful tax exemptions. Ironically, says MacIntyre, it is this highly secured fiscal position which causes the universities' deterioration into "fragmented and partitioned

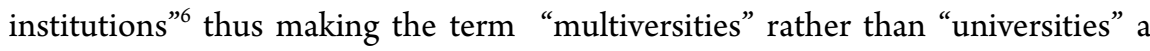
more appropriate appellation for them. MacIntyre explains:

What disappears from view in such universities, and what significantly differentiates them from many of their predecessors, is twofold: first, any large sense of and concern for enquiry into the relationships between disciplines and, second, any conception of the disciplines as each contributing to a single shared enterprise, one whose principal aim is neither to benefit the economy nor to advance the careers of its students, but rather to achieve for

\footnotetext{
${ }^{5}$ Alasdair MacIntyre. Three Rival Versions of Moral Enquiry: Encyclopedia, Genealogy and Tradition (Notre Dame: University of Notre Dame Press, 1990), 217.

${ }^{6}$ MacIntyre, God, Philosophy, Universities, 174.

(C) 2012 Jovito V. Cariño http://www.kritike.org/journal/issue 11/carino june2012.pdf ISSN 1908-7330 


\title{
6 IDENTITY OF CATHOLIC UNIVERSITIES
}

\author{
teachers and students alike a certain kind of shared \\ understanding. ${ }^{7}$
}

\section{The Idea of the University}

In his reflection on the identity of Catholic universities, MacIntyre returned to Cardinal Henry Newman's masterpiece, The Idea of University, which was written to assert the Catholic university's distinct mark as an institution of higher learning against the onslaught of secularism sweeping around the tail end of the $19^{\text {th }}$ century. For Newman as it is for MacIntyre, the university is a cradle of oneness, of commonality, of shared wisdom and collective experience. The university has always been the bastion of cultural exchange since its birth in the Middle Ages and even then, philosophy is deemed a prominent feature of its very structure. Universitas means total, the whole. It is a place where one finds an encounter with reality as a whole. Any person who comes to the university acquires a worldview that allows him to see the interconnected nature of the world and humanity at large and this, argues Newman, is something that a university can get only from philosophy which, says he, consists in "a comprehensive view of truth in all its branches, of the relations of science to science, of their mutual bearings and their respective values." 8 This is confirmed by the fact that among the highest degrees a university can confirm to its member is a doctoral degree in philosophy, a testament to one's ascent to a synthetic view of reality after years of rigorous study.

This concept of university however has been steadily eroded by the aggressive encroachment of the ill effects of globalization into the portals of institutions of higher education. While we cannot dismiss the wonders that science and technology have done in further shrinking the world into a compact global village and in making our operations and processes faster and more efficient, we cannot also turn a blind eye to the new form of manipulation that it has introduced by legitimizing effectiveness as the language of human activity and by imposing capital as the pivot point of human endeavor. In this environment, everything is assessed and measured for their fitness within the scheme of effectiveness. This is a challenge to the moral theorist since, as MacIntyre explained, "the whole concept of effectiveness is, as I noticed earlier, inseparable from a mode of human existence in which the contrivance of means is in central part the manipulation of human beings into compliant patterns of behavior and it is by appeal to his own effectiveness in this respect that the manager claims

\footnotetext{
${ }^{7}$ Ibid.

${ }^{8}$ John Cardinal Henry Newman, The Idea of University (New York: Image Books, 1959), 130. 
authority within the manipulative mode." We know this trend has infected universities when students distinguish between courses that are "in demand" and "not in demand" and categorize their subjects between "major" and "minor", that is, between those that are "more effective" and those that are "less effective" for their target careers. University education is deemed accomplished when a graduate gets hired, that is, when his skills match the ends imposed by corporate organizations.

The capitulation of the university education to purely economic aims has long taken root in the Philippine educational system, thanks to the institution of labor export as a state policy by the Marcos government way back $1974 .{ }^{10}$ That policy has not been revoked and its concomitant implementation relentlessly continued through various regime changes and two pseudo-revolutions. We see the apex of this school-is-equal-to-labor-is-equal-to-economic-progress mentality with the recent proposal of the government to extend basic education to 12 years and cut down higher education to 3 years. This move apparently is impelled by the government's desire to align the country with various international "accords" which now set the tone for the aims and processes of education all over the world. We can cite the likes of Bologna Process ${ }^{11}$ and Washington Accord ${ }^{12}$ as concrete examples of these agreements. Bologna Process is of European origin and whose basic aim is to harmonize university education across Europe. Washington Accord comes from the US and is dedicated to the accreditation of engineering programs among its signatory countries. By making our educational system compliant with these agreements, the government hopes to improve the Filipinos' employability in countries which endorse them. ${ }^{13}$ This move is welcomed by some academics who are unfriendly with the humanities, especially philosophy. They boldly foretell that this development signals the inevitable purge of what they usually label as excess baggage of the university curriculum. ${ }^{14}$ Such cavalier attitude

${ }^{9}$ Alasdair MacIntyre,, After Virtue (Notre Dame, Indiana: University of Notre Dame Press., 1984) .74

${ }^{10}$ See Bing Baltazar C. Brillo, "Path Dependence, Inreasing Returns and Philippine Labor Migration Policy” in Crossroads, 8:1 (2008), 24-61, <http://www.webasa.org/ Pubblicazioni/Brillo_2008 1.pdf >. See also Feina Cai. "The Labour Export Policy: A Case Study of the Philippines," in <http://www.e-ir.info/? p=12913 $>$.

11 For added information on the Bologna Process, see <http:// www.ond.vlaanderen.be/hogeronderwijs/bologna/about/index.htm $>$.

12 For added information on the Washington Accord, see <http:// www.washingtonaccord.org/Washington-Accord/>.

${ }^{13}$ For the implications of these accords to the Philippine educational system, see Isagani Cruz's articles "The Bologna Accord," in $<\underline{\text { http: //www.philstar.com/Article.aspx?articleid=540592 }>}$ and "The Washington Accord," in <http://www.philstar.com/Article.aspx?articleId=574687>

${ }^{14}$ For another take on the state of university education in the Philippines, see Raul Pangalangan's article “The Fetish for Global Rankings," in $<$ http://opinion.inquirer.net/12625/the- 


\section{IDENTITY OF CATHOLIC UNIVERSITIES}

dramatizes the kind of marginalization of philosophy which MacIntyre rebukes as undermining the very nature of university. MacIntyre wrote:

Yet in the contemporary research university neither philosophy nor theology can find their due place. Theology has for the most part been expelled altogether from the research university. Philosophy has been marginalized in two ways. First, it is at best treated as no more than one discipline among all the others, a discipline with no more claim to the attention of students and their teachers than any other discipline has. In so far as it produces students well prepared for their further careers, it is valued just as every other such discipline is valued. But the notion that human beings need philosophy, that philosophy articulates and moves toward questions the answering of which is crucial to human flourishing, this notion is wholly alien to the ethos of the research university. ${ }^{15}$

One wonders however what the university would be like without philosophy when from Athens to Alexandria, from Paris to Persia, from Madrid to Manila ${ }^{16}$, philosophy has always been the cornerstone of every learning center, of every university. Newman thought that university and philosophy are almost interchangeable that one cannot be thought without the other. He would say in fact that the teaching of "philosophical habit" is "the very purpose of a university." ${ }^{17}$

\section{Philosophy and University}

The academia and pursuit of wealth are strange bedfellows and stranger still is the situation where wealth dictates the university agenda. While the university fosters "life of the mind" and shared understanding through research, instruction and symposia, pursuit of wealth engenders individualism and alienation. There should be then that space to protect the university against the tendencies to turn it into a "professional school", that is, as a preparatory institution for feeding the needs of the professions. Hans-Georg Gadamer

fetish-for-global-rankings> and Randy David's "Education In A Competitive World," in <http://opinion.inquirer.net/12739/education-in-a-competitive-world>.

${ }^{15}$ MacIntyre, God, Philosophy, Universities, 175-176.

${ }^{16}$ It should be remembered that the Faculty of Philosophy was established in the same year that the University of Santo Tomas was granted the status of university, 1645.

${ }^{17}$ Newman, op. cit.,129.

(C) 2012 Jovito V. Cariño

http://www.kritike.org/journal/issue 11/carino june2012.pdf

ISSN 1908-7330 
explains: "The word, education, signified a distancing from everything profitable and useful. In its elevated sense, the 'science, which has not yet been completely discovered', means, 'living with ideas.' This should unify the youth at the university and is intended to disclose through knowledge the horizon for all of reality and thereby also to open the possibility of surpassing this reality." ${ }^{18}$ In other words, the purpose of the university is not just to create doctors, lawyers and architects but to imbue the same doctors, lawyers and architects with the spirit and the mind that will enable them to take on complex issues; to engage in constructive deliberation of pressing matters; to critique their own positions and be respectful of others'; to make their own prudent judgment. University education is meant, in other words, to transform the individual in those future doctors, lawyers and architects into members of society who can work well with teachers, engineers, clergy, jeepney drivers, market vendors and other members of the community towards a shared experience of human flourishing. The world of practical life is inherently fragmented, a perpetual "state of war" to use the description of Thomas Hobbes. It is a world torn by individuals' competing pursuit of external goods. ${ }^{19}$ The university therefore cannot concede its "solitude and freedom" to this state of affairs by becoming its mere subsystem. The university cannot afford to disintegrate into an institution of "many specialties" all in the name of the profitable. The university must not simply be an institution that lends itself as a laboratory for developing skills but as breeding ground for the cultivation of practices and virtues. ${ }^{20}$ What MacIntyre wrote about the dynamics between institutions, practices and virtues very well applied on the university as a microcosm of a human society. As an institution, the primary goal of university should be the cultivation of the human person able to grasp "a telos which transcends the limited goods of practices by constituting the good of a whole human life, the good of a human life conceived as a unity."21

The task of breeding this solidarity, this sense of community, this spirit of universality belongs to philosophy particularly in an age when the former is becoming more and more a rarity. One cannot overemphasize the teaching of philosophy in all levels of formal education. The UNESCO publication entitled Philosophy: A School of Freedom, discusses the necessity and significance of teaching philosophy in all levels of education, from basic, to secondary, to the university level. UNESCO, in the said document, tells us that teaching of philosophy in the university level ought not to be seen as mere "doctrinal training"

${ }^{18}$ Hans-Georg Gadamer, Hans-Georg Gadamer on Education, Poetry and History (New York: State University of New York Press, 1992,), 48.

${ }^{19}$ MacIntyre, After Virtue, 196.

${ }^{20}$ Alasdair MacIntyre,. Dependent Rational Animals: Why Human Beings Need Virtues (Illinois: Open Court, 1999), 102.

${ }^{21}$ MacIntyre, After Virtue, 203.

(C) 2012 Jovito V. Cariño

http://www.kritike.org/journal/issue 11/carino june2012.pdf

ISSN 1908-7330

\section{(cc) BY-NC}


on any philosophical system. A genuine philosophical education "aims to help individuals understand the complexity of experience. It also teaches us to critically consider established opinions, whether ours or those of others, and to criticize the motivations and intentions behind them and their effects. A philosophical education is a fundamental communication mechanism, because it is precisely by virtue of its critical range that we learn to see in another's world view not the expression of a particular and foreign subjectivity but a partner in a shared human interaction, with whom it is possible to have productive exchanges and dialogue. ${ }^{\prime 22}$ Teaching philosophy therefore is not just teaching another discipline; it is teaching rather a discipline of the mind that will enable an individual to navigate his way through the labyrinthine paths of human life simulated in the university. If life is a game, it can compare probably with a giant connect-the-dots and philosophy is that instrument that helps us trace and see what otherwise are dots in disarray hiding the intricate yet intimate pattern of our human existence.

\section{Thomistic Philosophy and the University of Santo Tomas}

How do all these then impact the University of Santo Tomas? I shall try to address this question by citing three reasons which I herewith call as reason of tradition, reason of vocation and finally, reason of mission.

Reason of tradition. UST is a Dominican institution. It means it shares in the charism of study and teaching of truth characteristic of the Dominican Order to which Thomas Aquinas belongs. It was for love of truth that Thomas Aquinas devoted a huge part of his teaching and preaching ministries. With the same zeal, the founder of this university, another Dominican, Fray Miguel de Benavidez, envisioned a center of learning which can be a portal of education ready to serve and be a dialogue partner of the Church and the society at large. That philosophy dates back to when UST was founded was no accident of nature. It points to the essential role that philosophy plays in the whole intellectual tradition of which UST herself is both a product and a contributor. The figures of philosophers like Plato, Aristotle, Augustine and Albert the Great which hover at the precipice of the UST Main Building are statements that their designer, Francesco Monti, wanted to make. They recall for us not only what UST stands for; they also disclose where UST stands on, that is, the search for and love of wisdom which characterize who we are as human beings. In teaching philosophy therefore, specifically, Thomistic philosophy, UST is simply carrying on a tradition bequeathed by its very name.

${ }^{22}$ UNESCO. Philosophy: A School of Freedom (Teaching Philosophy and Learning To Philosophize: Status and Prospects) (Paris, France: UNESCO, 2007), 113.

(C) 2012 Jovito V. Cariño

http://www.kritike.org/journal/issue 11/carino june2012.pdf

ISSN 1908-7330 
Reason of vocation. The vocation of a university vis-a-vis philosophy is well suggested by two landmark encyclicals, Aeterni Patris ${ }^{23}$ and Fides et Ratio, ${ }^{24}$ both of whom highlight the special role of Thomistic philosophy. In a limited perspective, the two encyclicals may be read as canonical endorsement of Thomism; but on a broader view, they may be seen as an underscoring of the role of philosophy in the search for truth to which UST as a Catholic university staunchly commits itself. In such search, philosophy is more than an accessory; it is in fact an indispensable complement of our efforts to better understand ourselves and the world. But far from a blind adherence to Thomistic philosophy, the study of philosophy in a university setting, MacIntyre adds in his reflection on Fides et Ratio, should enable us to see the inherent conflicts within the Catholic philosophical tradition and the requisite demand to debate and dialogue with the exponents of agreement and disagreement. ${ }^{25}$

Reason of mission. As a Catholic university, the University of Santo Tomas aims at forming individuals who can engage the world with virtues of competence, compassion and commitment. Thomasians therefore are envisioned by their university to be effective career practitioners, disciples of faith and global citizens. This is achieved by equipping them with a discipline that will enable them to see the world as a tapestry of inter-related meanings rather than a network of disparate and arbitrary truth claims. In his address commemorating the $100^{\text {th }}$ year of Aeterni Patris, the late John Paul II would point out that:

The philosophy of St. Thomas deserves to be attentively studied and accepted with conviction by the youth of our day by reason of its spirit of openness and of universalism, characteristics which are hard to find in many trends of contemporary thought. What is meant is an openness to the whole of reality in all its parts and dimensions, without either reducing reality or confining thought to particular forms or aspects (and without turning singular aspects into absolutes), as intelligence demands in the name of objective and integral truth about what is real. Such openness is also a significant and distinctive mark of the Christian faith, whose specific countermark is its catholicity. ${ }^{26}$

\footnotetext{
23 Leo XIII, "Aeterni Patris," in <http://www.vatican.va/ holy_father/ leo_xiii/encyclicals/documents/hf_l-xiii_enc_04081879_aeterni-patris_en.html >.

24 John Paul II, "Fides et Ratio" in <http://www.vatican.va/ holy_father/ john_paul_ii/encyclicals/documents/hf_jp-ii_enc_15101998_fides-et-ratio_en.html>.

${ }^{25}$ MacIntyre, God, Philosophy, Universities, 178-179.

${ }^{26}$ John Paul II, "Perennial Philosophy of St. Thomas Aquinas For The Youth of Our Times," a speech delivered to his alma mater, the Angelicum, on the occassion of the 100th anniversary of Leo XIII's Aeterni Patris in <http://www.bukal.com/lib_result.php?libid=592 $>$.
} 
Philosophy in general therefore and Thomistic philosophy in particular are natural endowments of the University of Santo Tomas; they are constitutive of its birthright. That it should be part of its core curriculum is in fact an understatement. This is not to say that Thomistic philosophy should be taught in UST in a straitjacket fashion. That is exactly what we should do if we aim to emasculate the genius of Thomas Aquinas. What we need to do is to teach Thomistic philosophy in the same spirit as he did, that is as critical, as dialogical and as open to the possibility beyond one's cherished intellectual position. Thomas Aquinas is the quintessential university man because of his global worldview. For Aquinas, philosophy is neither a dogma nor a mere intellectual persuasion but an essential articulation of who we are as human persons. The love of wisdom and the search for truth are drives that stem from our being human. The more in touch we are with our humanity, the more reasonable we shall be in our action and orientation. Agere sequitur esse, as he himself would say - we act according to our nature.

Our rationality, not Wi-Fi connection not fiber optics, not even Facebook, is what binds us as one human community. By rationality, we mean our ability to be open to each other in the spirit of respectful listening, our common search for what is true, our common desire for good, our collective struggle for justice and our mutual recognition of our need to be heard and to be understood. All of these bear on the "university", particularly, on a catholic university like the University of Santo Tomas. The word catholic shares the same nuance as the word university. Both of them allude to a sense of "all" or "common". When used by a university to refer to itself, it becomes both a statement and testament to its humanistic aspirations. It is also this human commonality which explains MacIntyre's correction of Aristotle. In his comment of this MacIntyrean improvement of Aristotelian position, Knight wrote:

Since correcting Aristotle on the inclusivity of political community, MacIntyre has corrected his own endorsement in Whose Justice? and Three Rival Versions of Aristotle's hierarchism. He now stresses our mutual dependence so that relations between practices are not of the asymmetrical kind whereby one aims at the benefit of another without reciprocity. Principles of just distribution and 'just generosity' contravene the hierarchical order of Aristotle's 'for the sake of relations, although MacIntyre persists in proposing the teleological nature of political order. The

(C) 2012 Jovito V. Cariño

http://www.kritike.org/journal/issue 11/carino june2012.pdf

ISSN 1908-7330 
rationale, and not just the intention, of his politics is now that of a thoroughly inclusive common good. ${ }^{27}$

The former Master General of the Dominican Order and Oxford professor, Timothy Radcliffe offers his own description of the global university. Radcliffe says the identity and mission of the university in the global age may be compared to the act of "talking to strangers." In his address to the graduates of Yale University, he explains:

But if universities are to train us in the delicate art of talking to strangers, then it is not enough that we struggle with texts and try to understand the dead. Ultimately a university will contribute to the building of human community and to the art of dialogue if we are able to talk with each other. Newman once wrote that if he had to choose between a university with highly trained professors, rigorous examinations and which taught the pupils lots of facts, or one in which a lot of young people merely met and debated with each other, then he would without hesitation choose the latter. Because the primary function of a university is to teach us to be social beings, able to talk, to listen and learn from those who are different. ${ }^{28}$

This is what Aquinas did in his time. He was talking to strangers - people outside his own historical situation, his own faith, his own intellectual circle. This is evidenced by the numerous disputatio he held in the University of Paris; by his intellectual dialogue with the pagan Aristotle and the Islamic thinkers such Averroes and Avicenna and the Jewish scholar Moses Maimonides; by the letters and constitutions he wrote for various bishops and monarchs. The very structure of Summa Theologiae itself, the parade of all the views Aquinas agreed and disagreed with, is a veritable testament to his commitment to dialogue. It was not surprising that the great Renaissance Dante counted him as his primary influence. $^{29}$ The great humanist crusaders in the persons of Bartolome de las Casas and Francisco de Vitoria were themselves Thomist scholars. ${ }^{30}$ de Vitoria

${ }^{27}$ Kelvin Knight, Aristotelian Philosophy: Ethics and Politics From Aristotle to MacIntyre (Cambridge, UK: Polity Press, 2008), 179.

${ }^{28}$ Timothy Radcliffe, "Talking To Strangers" in <http://www.dimensionesperanza.it/ english-articles/item/6400-talking-to-strangers-timothy-radcliffe-op.html>.

${ }^{29}$ Paul Johnson, The Renaissance: A Short History (New York: The Modern Library, 2002), 25

${ }^{30}$ Paul S. Vickery, Bartolome de las Casas: Great Prophet of the Americas (New Jersey: Paulist Press, 2006), 15-22.

(C) 2012 Jovito V. Cariño

http://www.kritike.org/journal/issue 11/carino june2012.pdf

ISSN 1908-7330 


\section{IDENTITY OF CATHOLIC UNIVERSITIES}

himself, the acknowledged pioneering mind of international law, ${ }^{31}$ was the mentor of Domingo de Salazar, another Dominican who would later be the first bishop of Manila and well-remembered in the annals of Philippine history as a missionary protector of Philippine natives and a close associate of the founder of a small school which will be later known as University of Santo Tomas. ${ }^{32}$

\section{Conclusion}

To go back to the question I posed in the beginning, What does it mean to be a university in the global age?, I then say that to be a university in the global age is to be that sphere whose members freely engage in their common pursuit for a shared search and understanding of truth. Thomas himself would say in $D e$ Magistro, we are able to "discover" truth only if we allow others to help us. ${ }^{33}$ This commonality which the university fosters is an important element for the transformation of its students into responsible global citizens, that is, individuals who see each other as members of the same human community, aspirants of the same human flourishing and partakers of the same human experience that characterize our common finitude. The university, therefore, cannot dispense with the humanities in general and philosophy in particular, if it wishes to assert its identity in the global age for these are the very disciplines that will help its students discover what defines them as human persons. It is through the cultivation of sympathy and the nurturing of philosophical mind that the university can help deter the alienation and manipulation engendered by unhampered consumerist culture and uncritical utilization of science and technology characteristic of the global age. In its celebration of its fourth centenary, the University of Santo Tomas defines its birthright and destiny in terms of building the church, the nation and family. This is to say that to be a university means to be a living summa, a place that gathers fellow pilgrims in search of that common fiber woven through the layers of differences in our individual lives. As a university, UST is an alma mater, the breeding ground from which the sense of humanity of its members acquires its soul.

Department of Philosophy, University of Santo Tomas, Philippines

\footnotetext{
${ }^{31}$ Francisco de Vitoria, Political Writings, ed. by Anthony Pagden and Jeremy Lawrance (The Edinburgh Building, Cambridge, UK: Cambridge University Press, 1991), xiii-xxvii.

${ }^{32}$ Horacio de la Costa, SJ, "Bishop Salazar and the Colonial Episcopate" in Selected Studies in Philippine Colonial History. (Quezon City, Philippines: 2B3C Foundation, 2002), 66-92.

${ }^{33}$ Thomas Aquinas, "De Magistro, Q. 11, Ar. 1 -2" in De Veritate, trans. by James V. Mcglynn, SJ (Indianapolis: Hackett Publishing Co., Inc., 1994), 77-90.

(C) 2012 Jovito V. Cariño http://www.kritike.org/journal/issue 11/carino june2012.pdf ISSN 1908-7330 


\section{References}

Aquinas, Thomas, De Veritate, trans. by James V. Mcglynn, SJ (Indianapolis: Hackett Publishing Co., Inc., 1994).

Bologna Proces in <http://www.ond.vlaanderen.be/hogeronderwijs/ bologna/about/index.htm>

Brillo, Baltazar C., "Path Dependence, Inreasing Returns and Philippine Labor Migration Policy" in Crossroads, 8:1 (2008), 24-61, $<\underline{\text { http://www.webasa.org/Pubblicazioni/Brillo_2008 1.pdf }>}$

Cai, Feina, "The Labour Export Policy: A Case Study of the Philippines," in $<$ http://www.e-ir.info/?p=12913 >.

Cruz, Isagani, "The Bologna Accord," in http://www.philstar.com/ Article.aspx?articleid $=540592$.

, "The Washington Accord," in <http://www.philstar.com/ Article.aspx?articleId $=574687>$.

David, Randy, "Education in a Competitive World," in $<$ http://opinion.inquirer.net/12739/education-in-a-competitiveworld $>$.

de la Costa, Horacio, Selected Studies in Philippine Colonial History, ed. by Roberto Paterno (Quezon City, Philippines: 2B3C Foundation, 2002).

de Vitoria, Francisco, Political Writings, ed. By Anthony Pagden and Jeremy Lawrance (The Edinburgh Building, Cambridge, UK: Cambridge University Press, 1991).

Friedman, Tom, The Lexus and The Olive Tree (New York: Anchor Books, 2000). , The World Is Flat (New York: Picador, 2007).

Gadamer, Hans-Georg, Hans-Georg Gadamer on Education, Poetry and History (New York: State University of New York Press, 1992).

John Paul II, "Fides et Ratio" in <http://www.vatican.va/ holy_father/john_paul_ii/encyclicals/documents/hf_jpii_enc_15101998_fides-et-ratio_en.html>. , "Perennial Philosophy of St. Thomas Aquinas For The Youth Of Our Times" in <http://www.bukal.com/lib result.php?libid=592> . , The Renaissance: A Short History (New York: The Modern Library, 2002).

Knight, Kelvin, Aristotelian Philosophy: Ethics and Politics From Aristotle to MacIntyre (Cambridge, UK: Polity Press, 2008).

Leo XIII, “Aeterni Patris" in <http://www.vatican.va/holy father/ leo_xiii/encyclicals/documents/hf 1-xiii_enc_04081879_aeternipatris en.html>. 


\section{IDENTITY OF CATHOLIC UNIVERSITIES}

Lumbera, Bienvenido et al ed., Mula Tore Patungong Palengke: Neoliberal Education in the Philippines (Quezon City, Philippines: IBON Foundation, 2007).

Lyotard, Jean-Francois, The Postmodern Condition: A Report On Knowledge (Minneapolis: University of Minnesota Press, 1999).

MacIntyre, Alasdair, After Virtue (Indiana: University of Notre Dame Press, 1984).

Dependent Rational Animals: Why Human Beings Need Virtues (Illinois: Open Court, 1999)

, God, Philosophy, Universities: A Selective History of the Catholic Philosophical Tradition (Plymouth, UK: Rowman \& Little Publishers, Inc., 2009).

,Three Rival Versions of Moral Enquiry: Encyclopedia, Genealogy and Tradition (Notre Dame: University of Notre Dame Press, 1990).

Newman, Cardinal John Henry,The Idea of University (New York: Image Books, 1959).

Pangalangan, Raul, "The Fetish for Global Rankings" in <http:// opinion.inquirer.net/12625/the-fetish-for-global-rankings $>$.

Radcliffe, Timothy, "Talking To Strangers," in <http:// www.dimensionesperanza.it/english-articles/item/6400-talking-tostrangers-timothy-radcliffe-op.html $>$.

UNESCO, Philosophy: A School of Freedom (Paris, France: UNESCO, 2007).

Vickery, Paul S., Bartolome de las Casas: Great Prophet of the Americas (New Jersey: Paulist Press, 2006). 